\title{
A BÜROKRATIKUS SZERVEZETEK INFORMÁCIÓS INFRASTRUKTÚRÁJÁNAK DIGITALIZÁLÁSA
}

\author{
Cseh Gergely \\ egyetemi tanársegéd, Miskolci Egyetem, Államtudományi Intézet, Közigazgatási Jogi Tanszék \\ 3515 Miskolc, Miskolc-Egyetemváros, e-mail: jogcsehg@uni-miskolc.hu
}

\section{Paulovics Anita}

egyetemi tanár Miskolci Egyetem, Államtudományi Intézet, Alkotmányjogi Tanszék 3515 Miskolc, Miskolc-Egyetemváros, e-mail: jogani@uni-miskolc.hu

\begin{abstract}
Absztrakt
Az tanulmány célja, hogy megpróbálja összefoglalni, hogy a kutatás keretében milyen megállapitásokat tettünk a bürokratikus (közigazgatási) szervezetek elméleti alapja és infrastrukturális fejlődése kapcsán. Az elmúlt idöszakban a közigazgatás modernizációja lendületet vett, ezért úgy véljük, hogy érdemes figyelmet fordítani arra, honnan indult az ügyintézés kialakitott rendje, és hol tart ma a digitális közigazgatás fejlesztési lehetöségei terén. Jelen összegzö tanulmányban nem a teljes digitalizációs folyamatot fogjuk vizsgálni, hanem csupán a bürokrácia alapfogalmait és a bürokratikus szervezetek back office folyamatait támogató, a közigazgatás alap infrastruktúrájának fejlödési állomásait, kitérve az önkormányzati vetületekre is.
\end{abstract}

Kulcsszavak: bürokrácia, legális uralom, társadalmi innováció, digitalizáció

\begin{abstract}
The aim of the study is to try to summarize the findings of the research regarding the theoretical basis and infrastructural development of bureaucratic (administrative) organizations. Recently, the modernization of public administration has gained momentum. Therefore, we believe that it is worth paying attention to where the administration started and where it stands today in terms of the development opportunities of digital administration. In this summary study, we will not examine the whole digitization process, but only the basic concepts of bureaucracy and the development stages of the basic infrastructure of public administration supporting the back office processes of bureaucratic organizations, including municipal aspects.
\end{abstract}

Keywords: bureaucracy, legal domination, social innovation, digitization

\section{Szervezeti innováció - bürokrácia}

A bürokrácia kifejezést a 18-ik századtól kezdték használni. A szó onnan származik, hogy a francia feudális abszolutizmus miniszteri irodáinak (bureau) döntő hatalma (kraté) lett az ország ügyeinek vitelében. Így abban az időben a bürokrácia elnevezés alatt azt a hivatásos közszolgálatot értették, mely állandó hivatali szervezettel, folyamatosan müködött. Mindent írásba kellett foglalni, iktatni és jegyzőkönyvbe venni, a jegyzőkönyvet pedig hitelesség céljából alá kellett írni. Így örökítették meg a hatóságok tevékenységét (acta), és innen származik az ügyiratok megjelölésére ma is használatos akta kifejezés. Az eljárás ezzel párhuzamosan egyöntetübbé vált. A hasonló ügyekre gyakran hasonló ügyintézést alkalmaztak [1]. A 19-ik században a bürokrácia kifejezés olyan uralkodási-kormányzási 
rendszert jelentett, amelyben a hivatalnokokat kinevezték, az uralkodótól függtek, és a monarchia alattvalói voltak. Az 1920-as évektől a terminológia Max Weber - lentebb bemutatott - munkája nyomán terjedt el, aki azt relatíve pozitív folyamatnak tekintette. Annak ellenére, hogy 1944-ban Ludwig von Mises osztrák közgazdász megjegyezte, hogy a bürokrácia kifejezés mindig hordozott egy "gyalázatos" mellékértelmet, 1957-ben Robert Merton amerikai szociológus azt írta, hogy a "bürokrata" egy "díszítő jelzővé" vált [2].

A bürokrácia szónak mindennapjainkban negatív kicsengése van. "Gondolatunkban az aktahegyek mögött trónoló hivatalnok jelenik meg, aki az élettől eltávolodva, a puszta szabályzatok és elöírások tömegében kutatva, az élet által felvetett egy-egy problémára csak a papírosnak megfelelő megoldást keres. A bürokrata rideg gépember, akinek nincs érzéke az iratokból kiáradó kérdések iránt. Ha a betükön és a paragrafusokon kívül valamire figyel, az csupán az, hogy állásfoglalása, döntése a formáknak megfelelő legyen, a hivatal által képviselt érdekeket szolgálja, s egy hivatalvizsgálat ne találjon munkájában semmi észrevételezni valót. [3]"

A közigazgatás korszerüsítéséhez - úgy véljük - együttesen szüksége a közigazgatás szervezeti innovációja és a digitális ügyintézés alkalmazhatósága. A szervezeti innováció szempontjából pedig nem lehet figyelmen kívül hagyni annak történeti-tudományos előzményeit, melyek elsősorban Max Weber nevéhez kapcsolhatóak.

\section{Weber bürokrácia elmélete}

Weber szervezetnek egy kifelé szabályozott korlátokkal vagy zárt társadalmi kapcsolatot nevez, akkor, ha a kapcsolat rendjének betartását az biztosítja, hogy bizonyos emberek - egy vezető, esetleg az igazgatásban résztvevők csoportja - arra specializálják a viselkedésüket, hogy érvényt szerezzenek a rendnek [4]. Weber a szervezetek különféle típusait különbözteti meg. Eszerint a szervezet lehet autonóm vagy heteronóm, illetve autokefális vagy heterokefális. Az autonómia azt jelenti, hogy a szervezet rendjét nem kívülállók írják elő, mint heteronómia esetén, hanem a szervezethez tartozó társak, mégpedig társi minőségükben. Az autokefália azt jelenti, hogy a vezetőt és a szervezet élén álló csoportot a szervezet saját rendjének megfelelöen nevezi ki, és ebbe kívülállók nem szólnak bele, mint heterokefáliánál. [5] A legitim uralomnak Weber három tiszta típusát különböztette meg: legális-, tradicionális- és karizmatikus uralom. Ha az uralom megfelel a tételes rendnek, akkor a legálisan, törvényekben rögzített dologi és személytelen rendben, valamint az e rend által kijelölt elöljárónak - az általa hozott rendelkezések formális legalitása folytán és körén belül - engedelmeskednek [6]. Weber a legális uralmat tartja a fenti kategóriák közül a legjobbnak. A bürokratikus müködés jellemzöit Weber a legális uralommal kapcsolatban fejti ki elsősorban. A legális uralom legtisztább típusának Weber azt tekinti, amikor bürokratikus igazgatási csoportot vesznek igénybe az uralom gyakorlásához. Ezzel kapcsolatban fejti ki a szerző - a témánk szempontjából fontos - bürokratikus igazgatás jellemzőit, melyek a következőképpen foglalhatóak össze. Az igazgatást végző csoport egésze hivatalnokokból áll, és egy személy vezetése alatt müködik, azaz nem érvényesül a testületi vezetés elve. A hivatalnokok rögzített hivatali hierarchiában helyezkednek el, hivatali hatáskörük rögzítve van, állásukat szerződés alapján töltik be, tehát szabadon választják ki őket és szakképzettségük alapján alkalmazzák őket, fix fizetést kapnak, hivataluk jelenti a fö foglalkozásukat, hivatali pályafutásuk a szolgálati időnek és/vagy a teljesítménynek megfelelő előmenetelt jelent, szigorú hivatali fegyelem és ellenőrzés alatt állnak. Ez a bürokratikus rend Weber szerint egyformán jellemző az állami szerveknél éppúgy, mint a gazdálkodó szerveknél (például üzemeknél) vagy a politikai szervezeteknél [7]. Weber álláspontja az volt, hogy a tisztán bürokratikus igazgatás - tehát az írásos ügyvitelen és egyszemélyi vezetésen alapuló, monokratikus-bürokratikus igazgatás - pontosság, állandóság, fegyelem, szilárdság és megbízhatóság 
tekintetében, valamint az egyetemleges alkalmazhatóság tekintetében a lehető legnagyobb tökélyre fejleszthető, vagyis formálisan a legracionálisabb formája az uralom gyakorlásának [8]. Weber elméletéből különösen kiemelendőnek tartjuk az írásos ügyvitel elemét, mivel az írásbeliség minden bürokrácia, így például már az egyiptomi vagy babiloni bürokráciának is feltétele volt. Napjainkban pedig éppen az írásbeliség képezi alapját a digitalizáció jelentőségének.

Weber bürokrácia modelljét elsősorban a modell túlzott formalizmusa miatt támadták arra utalással, hogy Webernél a bürokratikus szervezet egy személytelen együttmüködési formát jelent, amelyben minden hatalom az elsőszámú vezető kezében összpontosul [9].

\section{Bürokrácia és közigazgatás}

Az egyre növekvő állami beavatkozások és közszolgáltatások hosszú időn keresztül a Weber nevéhez füződő bürokrácián, hierarchikus szervezeti struktúrán, formalizált eljárásokon és cél-orientált hivatali apparátuson alapultak. Ennek eredményeként a közszolgáltatást végzö szervek bürokratikusak és monolitikusak voltak. A közszolgáltatást végzö szerveket elsősorban azzal a céllal hozták létre, hogy válaszokat adjanak a jogalkotás során felmerült kérdésekre, és újabb közszolgáltatási megoldásokat alakítsák ki, figyelembe véve a politikai, gazdasági és társadalmi folyamatokat, illetve célokat. A közszolgáltatást végző szervek - amelyek jórészt közigazgatási szervek - így autonómia nélkül müködtek, szigorú pénzügyi ellenőrzés alatt álltak, és feladataikat rutinszerüen látták el a felsőbb hatóságok - föhatóságok - által meghatározott szabályok és eljárási rend keretén belül [10]. Valószínűleg maga Weber is tisztában volt azzal, hogy a bürokráciára vonatkozó klasszikus elmélete a későbbiekben további elemekkel egészülhet ki, ahogyan az meg is történt a gazdaságilag fejlett, demokratikus társadalmakban. A gazdasági- társadalmi- politikai változások ellenére a bürokrácia meghatározó tendencia maradt, ahogyan a Weber által meghatározott elemei is a közigazgatásban, így a hierarchia, a felelősség, az ésszerüség, a teljesítmény-orientált müködés, a specializáció, a fegyelem és a szakszerüség [11].

Úgy véljük Weber bürokrácia-elmélete napjainkban is igaz, és természetesen a bürokrácia is müködő formáció, ugyanakkor felgyorsult, folyamatosan változó világunkban a közigazgatásnak és a bürokráciának is alkalmazkodnia kell a változó körülményekhez.

A közigazgatás egyre több információval és adattal dolgozik, amelyeket fel kell dolgozni, esetenként továbbítania, és arra alapozva döntést hoznia. A bürokrácia sem létezik a szervezeten belüli és a szervezet és a külvilág közötti folyamatos információáramlás nélkül. A közigazgatás egyik legfőbb tevékenysége éppen a társadalom állapotának ismerete, amihez információkra van szükség. Ezt a célt szolgálják például a különböző statisztikák, vagy a nyilvántartások. A közigazgatási tevékenységek döntő része az információk megszerzése, ellenőrzése, szürése és feldolgozása. A közigazgatás már korábban is óriási adatmennyiséggel dolgozott, például egy népszámlálás esetében. Az utóbbi évtizedekben a közigazgatás által kezelt információk mennyisége a többszörösére nőtt. A bürokratikus szervezetek müködésének további fontos eszközei az információáramlás hatékony biztosítása, ellenőrzése és szabályozása. A digitalizálás jelentős mértékben átalakítja a bürokratikus szervezetekben az információáramlást, azaz a kommunikációt. Korábban a távközlés - távirat, telefon - és a közlekedési eszközök megjelenése, illetve fejlődése váltott ki hasonló hatást, de mértékét tekintve jóval kisebbet, mint a digitalizáció. "Egy bürokratikus rendszerben az információ átvételének szintje nem egyezik meg az információ feldolgozásának szintjével, sőt az információfeldolgozás szintje sem egyezik meg a döntéshozatal szintjével." [12] Egy ilyen folyamat jelentős időveszteséget eredményez, melynek megoldását szolgálhatja a magas szakértelemmel rendelkező hivatali apparátus, a szakemberek, valamint a digitális nyilvántartások és a digitális ügyintézés széleskörüvé tétele. A közigazgatás 
birtokában lévő óriási adatmennyiség kezelését teszi hatékonyabbá a digitális kommunikáció (információ-megosztás).

\section{A bürokratikus szervezetek digitalizációjáról általában}

A digitalizáció mélyebb vizsgálata előtt fontosnak tartjuk, hogy valamiféle meghatározást adjunk róla. „A digitalizáció az analóg vagy offline termékek és folyamatok, struktúrák transzformációja, amelynek során egy fizikai mennyiséget számítógéppel feldolgozható állapotba hozunk, ezáltal hatékonyabb, könnyebben hozzáférhető, optimális megoldások születnek. A digitalizáció lehetővé teszi valamennyi input (például szöveg, kép, hang) digitális térbe helyezését, ezen keresztül megváltoztatja az értékteremtést, új irányt szab valamennyi szervezet müködésének." [13] Az ismertetett értelmezés is megerősíti azt, hogy a digitalizáció által optimálisabb, hatékonyabb lehet a közigazgatási munkavégzés, továbbá a digitalizáció új értékek, eredmények teremtésére ad lehetőséget.

Úgy véljük, hogy a bürokratikus szervezetek digitalizációja szükséges, meggátolhatatlan és folyamatosan megújuló, innovatív folyamat. A bürokratikus müködésben megvalósuló innováció alapvetően kétféle lehet. Egyrészt technológia, másrészt társadalmi. Technológia innovációról beszélünk, amikor a bürokratikus szervezet eszközeinek újítása, cseréje történik meg vagy egy olyan új eszközt alkalmaznak a közigazgatásban, amely eddig ismeretlen volt. Társadalmi innovációról pedig akkor kell szót ejtenünk, ha ezeknek az új technológia megoldásoknak a nyomán az ügyintézők és a különböző közigazgatási szervek egymás közötti ügymenetei hatékonyabbakká, gyorsabbá válnak, vagy az ügyféli oldal könnyebben tud - a digitalizáció adta fejlesztések által - hozzáférni a közszolgáltatásokhoz.

\section{A bürokratikus szervezetek „digitalizációjának” lépései Magyarországon}

A digitalizáció azért került idézőjelbe a fejezetcímben, mert a bürokratikus szervezetek igazgatása során megvalósult fejlődési folyamatokat, akkor még „nem ezzel a jelzővel illették”. Az 1960-as 1970-es években kezdtek napvilágot látni olyan tanulmányok, kormányzati döntések, melyek a közigazgatás gépesítését [14], automatizálását [15] kívánatosnak és elkerülhetetlennek tartották [16]. „Az első közigazgatási adatkezelési megoldásokat, ügyviteli rendszereket már az 1970-es években használni kezdték Magyarországon, és az e-közigazgatási fejlesztések is ebben az időben indultak el a számítástechnika és a számítógépek terjedésével párhuzamosan.” [17] Az akkori kezdeményezésekről kapunk képet Kalas tanulmánya alapján: „A Magyar Szocialista Munkáspártnak az államigazgatás fejlesztésére vonatkozó célkitüzéseit az 1970-es évek elején több felső szintủ állami határozat bontotta le konkrét feladatokká. Ezek között kapott helyet az államigazgatás gépesítésének feladatköre is.” [18] Ekkor még az állami vezetők arra kívántak választ találni, hogy az igazgatás (a bürokratikus szervezet) mely területei alkalmasak a gépesítésre. Ahogy a bevezetőben említettük, ezen összefoglalóban kitérünk az önkormányzatok digitális innovációjára is. Rögzíthetjük, hogy digitalizációs szempontból a helyi szintű igazgatáshoz képest a közigazgatás többi része mindig is előbbre tartott. Ezt alátámasztandó Kovacsics 1972-es gondolata, miszerint a tanácsi igazgatásban „nemcsak a lyukkártyás, lyukszalagos, mágnesszalagos, illetve a random tárolásos (tömegtárolásos) módszerek nem vonultak be, de még szinte alig tettünk lépéseket a mikrofilmek útján való adattárolás felé..." [19]

Az informatika fejlödése, a technikai forradalom vívmányai azonban egyre inkább teret követeltek maguknak a közigazgatás különböző szintjein is, és már nem gépesítés - automatizálás fogalmi eltéréseit helyezték a középpontba. „Tény az, hogy az informatika sokkal inkább építő, átalakító szerepet tölt be a közigazgatásban, mint bármely más szervezetnél..." [20] Az informatikai vívmányok közül a 
számítógép emelhető ki, amely már ekkor is lényegesen beleavatkozott a bürokratikus müködés állóvizébe.

A központi államigazgatás szervei már a területi - helyi szerveket megelőzve alkalmaztak számítógépeket. Ennek oka, hogy az államigazgatási szervek rendszereiket az egész országra kiterjedően müködtethették, míg a tanácsok csak saját illetékességi területükön. 1975-ben létrehozták az Államigazgatási Számítógépes Szolgálatot, amely több államigazgatási szerv adatfeldolgozási feladatait hajtotta végre [21]. A tanácsok számítógéppel való ellátásának több gátja (személyi-, pénzügyi- és tárgyi feltételek [22]) is volt.

Ennek ellenére - az akadályok feloldását követően - a tanácsi információs (számítógéppel támogatott) mintarendszerek kialakítása több megyében, városi tanácsban elkezdődött, azért, hogy a területi, helyi szintű információkat a felhasználás helyén tartsák.

„Az 1980-as évek elejére bizonyossá vált, hogy a számítástechnika lehetőségeit a központi szervek még koránt sem merítették ki, és a fejlesztések révén gyakorlatilag ma még beláthatatlan fejlődés részesei lehetünk." [23] A tanácsok esetében is jelentős előrelépés történt a 80-as években és számos nyilvántartást, programot hoztak létre [24]. Az elkövetkezendő évek vissza is igazolták, hogy a közigazgatás számítástechnikai fejlesztésének, informatizálásának eddigi lépései még csak a „felkelő nap hajnali sugarai" voltak [25].

A bürokratikus szervezetek informatizálásának „első lépcsőfokát” tehát a számitógépek, számítógép rendszerek közigazgatásban történő alkalmazása jeleníti meg. A számítógép alkalmazás társadalmi innovációs hatása föként a közigazgatási szervek információ feldolgozásának komplexebb, gyorsabb és hatékonyabb megvalósítását eredményezte.

A közigazgatás digitalizációs fejlődésének következő lépcsőfoka az adatbázisok megjelenése volt. Azonban azt is rögzíthetjük, hogy az adatbázisok bürokratikus rendszerben való alkalmazása mondhatni „párhuzamosan”, a számítógépesítés első szakasza után kezdett el kibontakozni.

A számítógépes adatbázisok megvalósításához elengedhetetlen követelmény volt az, hogy a papír alapon meglévő nyilvántartásokat „felvigyék” a számítógépes rendszerekbe.

Azonban, az ekkor létrehozott adatbázisok még nem minősültek a mai, modern értelemben vett digitális adatbázisnak. Ezért is fontos továbbá azt is érzékeltetni, hogy a papír alapon rögzített adatok informatizálása lényeges innovációt hordozott magában. Amellett, hogy az addig materiálisan meglévő adatokat egy számítógépes adatbázisba transzformálták, az ügyintézői oldalnak - ugyanúgy, ahogy a számítógépesítés esetén - is adtak egy új lökést a hatékonyabb, gyorsabb bürokratikus munkavégzés irányába. Az előző gondolat első része technológiai innovációként, a második része pedig társadalmi innovációként azonosítható. Példaként említhetjük az ingatlan-nyilvántartás informatizálását, amely kezdetben az államigazgatás központi szintjén jelent meg, és ebben változást csak az ingatlannyilvántartásról szóló 1972. évi 31. törvényerejü rendelet módosításáról szóló 1994. évi V. törvény 11. §-a hozott, amely kógens szabályként rögzítette, hogy a településeknek az ingatlan-nyilvántartást elektronikus gépi adatfeldolgozással kell rögzíteni.

A digitalizáció következő lépcsőfoka a gerinchálózatok közigazgatásban való megjelenése volt. Hazánkban az Elektronikus Kormányzati Gerinchálózat (EKG) volt a témánk szempontjából első nevesített [26] gerinchálózat. Létrehozásának célja a kormányzati és közigazgatási adatbázisok és informatikai rendszerek összekapcsolása, az általuk nyújtott szolgáltatások elérhetőségének biztosítása, amelyhez nagysebességü külső Internet-csatlakozást biztosítottak. Az EKG összekapcsolta mindazt a fejlesztést (számítógéprendszerek és adatbázisok), amelyről az elözőekben beszéltünk.

A gerinchálózat EKG néven egészen 2013-ig müködött, majd 2013. május 30-től Nemzeti Távközlési Gerinchálózatra (NTG) keresztelték át [27]. Az NTG feladatai természetesen a technológia rohamos fejlődésével párhuzamosan folyamatosan változtak, kibővültek. Egyik ilyen kiemelt feladata 
,az eddig elszigetelt (szigetszerü) közigazgatási háttérszolgáltatások elérhetővé tétele a jogosult felhasználók számára.” [28]

Ahogy már föntebb is említettük, az EKG/NTG összefogta a közigazgatás eddigi digitális fejlesztéseit. Ezáltal a szervek közötti kommunikáció (értjük ezt akár a rendszerekre, akár az ügyintézőkre), az elszigetelt adatbázisok között információáramlás és az az elektronikus ügyvitel és ügyintézés feltételeinek megteremtése javult.

A back office folyamatok támogatására, a digitalizáció következö lépcsőjeként az információs rendszerek közigazgatásban való alkalmazását kell kiemelnünk. A közigazgatási szervek - vállalati mintára - kezdtek el információs rendszereket használni a bürokratikus szervezet „mindennapi életének” könnyítésére és az információk hatékonyabb felhasználására. Az információs rendszerek ráépülnek az eddigi fejlesztésekre, használják a már megszerzett információkat és segítik, támogatják a döntéshozatalt.

„A közigazgatásban még nem terjedt el a vezetői információs rendszerek, adatelemző rendszerek széles körű használata, de a tárolt és használt információ mennyiségének robbanásszerü növekedésével, valamint az alkalmazások fejlődésével várható, hogy a közeljövőben egyre nagyobb igény lesz ezekre a szolgáltatásokra is.” [29] Ennek több oka is lehet: korlátozott a gyüjtendö információk köre vagy korlátozott a szakmai felhasználók köre. Tény az, hogy széleskörben az elöbb megjelölt speciális információs rendszereket nem alkalmazzák a közigazgatásban, azonban ha a helyi szintü igazgatásra tekintünk, hazánkban már az összes önkormányzat használja az önkormányzati ASP rendszert, amely távoli alkalmazásszolgáltatást nyújtó elektronikus információs rendszer [30]. Az ASP bevezetése az önkormányzati igazgatási szervezetrendszerben dolgozók számára jelentős segítséget nyújtott az által, hogy azonos rendszerben dolgoznak és ez a tanulási, rendszer megismerési folyamatban is lényeges segítség. Az ASP-t biztosító szervek (Magyar Államkincstár, NISZ Zrt. stb.) nem csak a háttérinfrastruktúra üzemeltetést, a rendszerfelügyelet terheit veszik le a felhasználó önkormányzatok válláról, hanem a szoftverüzemeltetést, a jogszabálykövetést, a frissítések telepítését, és a HelpDesk szolgáltatások nyújtását is ellátják. Az ASP központi megoldása révén nagyobb potenciált biztosít, hogy egyéb központi nyilvántartások, szolgáltatások elérése biztosított legyen az önkormányzatok számára.

\section{A kutatás záró gondolatai}

„A közigazgatás jó ideje hasznosítja a technikai vívmányok biztosította előnyöket, gondoljunk csak a különböző nyilvántartások számítógépesítésére, illetve sokoldalú információs rendszerek kialakítására." [31] A technológia vívmányok elengedhetetlenül szükségesek a bürokratikus rendszerbe beérkezö, azon átmenő információk kezeléséhez, rendszerezéséhez. Hangsúlyozandó ugyanakkor, hogy egy technológiai újítás alkalmazása „csupán” egy eszköz a bürokratikus szervezetek információgyüjtési, igazgatási folyamataiban. Az információ gyüjtést-, kezelést természetesen a digitalizáció nélkül is meg tudná oldani a közigazgatás, azonban a technológia rohamos fejlődése ellen „o” sem tud tenni és persze nem is akar. Az innovatív fejlesztések - ahogy már többször is említettük - kifejezetten jótékony hatással vannak a bürokratikus szervezetek müködésére, amelyre az EFOP keretében végzett kutatás is több ponton rámutatott. Az összegző tanulmányban kitértünk a bürokrácia alapjaira és a bürokratikus közigazgatási - szervezetek infrastruktúrájának digitalizálási lépéseire. A kutatás során több tanulmányban rámutattunk arra, hogy ezen fejlesztések társadalmi innovációs vetületei jelentősek. 


\section{Köszönetnyilvánítás}

A cikkben ismertetett kutató munka az EFOP-3.6.1-16-2016-00011 jelű „Fiatalodó és Megújuló Egyetem - Innovatív Tudásváros - a Miskolci Egyetem intelligens szakosodást szolgáló intézményi fejlesztése" projekt részeként - a Széchenyi 2020 keretében - az Európai Unió támogatásával, az Európai Szociális Alap társfinanszírozásával valósul meg.

\section{Irodalom}

[1] Czizmadia, A.: Bürokrácia és közigazgatási reformok Magyarhonban. Gondolat Kiadó, Budapest, 1979., p. 6.

[2] Malik, J.: Publik Administration. https://www.academia.edu/8811037/bureaucracy (2018.10.20.)

[3] Czizmadia, A.: Bürokrácia és közigazgatási reformok Magyarhonban. Gondolat Kiadó, Budapest, 1979., p. 5.

[4] Weber, M.: Gazdaság és társadalom. A megértő szociológia alapvonalai. 1., Közgazdasági és Jogi Könyvkiadó, Budapest, 1987. p. 72.

[5] Weber, M.: Gazdaság és társadalom. A megértő szociológia alapvonalai. 1., Közgazdasági és Jogi Könyvkiadó, Budapest, 1987. p. 74.

[6] Weber, M.: Gazdaság és társadalom. A megértő szociológia alapvonalai. 1., Közgazdasági és Jogi Könyvkiadó, Budapest, 1987. p. 224.

[7] Weber, M.: Gazdaság és társadalom. A megértő szociológia alapvonalai. 1., Közgazdasági és Jogi Könyvkiadó, Budapest, 1987. p. 228.

[8] Weber, M.: Gazdaság és társadalom. A megértő szociológia alapvonalai. 1., Közgazdasági és Jogi Könyvkiadó, Budapest, 1987. p. 230.

[9] Torma, A.: Adalékok a szervezéstudomány irányzataihoz, Sectio Juridica et Politica, 2007/2. p. 471.

[10] Valkama, P., Bailey, S. J., Anttiroiko, A.-V.: Contexts and Challenges of Organizational Innovation in Public Service. Forms and Governance. Palgrave Macmillen, 2013. p. 5. https://doi.org/10.1057/9781137011848_1

[11] La Palombara, J.: An Overview of Bureaucracy and Political Development. In: La Palombara, Joseph: Bureaucracy and Political Development. Princeton University Press, 1963. p. 10. https://doi.org/10.1515/9781400875191

[12] Cziprián, K. L., Deme, C.: Igazgatás - közigazgatás - bürokrácia. Közigazgatás, Reform. http://epa.oszk.hu/00400/00458/00126/3487.html (2018.10.18.)

[13] Budai, B., Gerencsér, B. Sz., Veszprémi, B.: A digitális kor hazai közigazgatási specifikumai, Dialóg Campus, Budapest, 2018., pp. 17-18.

[14] Gépesítés az emberi munka részben gépi munkával való felváltását jelenti. A gépesítéssel a nyilvántartások hatékonyabb kezelését, az adattárolás fejlesztését tüzték ki célul. Kovacsics, J.: Az információs folyamatok gépesitése a tanácsi igazgatásban és a rendszerszervezés, Állam és Igazgatás, 1972/12. pp. 1090-1094.

[15] Automatizáláson az emberi munka teljes kiiktatását, gépi munkával való helyettesítését értjük.

[16] Lásd erről bővebben: Berényi, S.: A tudományos technikai forradalom és az államigazgatás, Jogtudományi Közlöny, 1972/10. pp. 485-491.; Kalas, T.: Számitógép az államigazgatásban. Közgazdasági és Jogi Könyvkiadó, Budapest, 1979.

[17] Kun, L.: Automatizálás a közigazgatásban? - Az informatikai alkalmazások trendjei a digitalizáció kiteljesedésének időszakában, Új Magyar Közigazgatás, 2017/2. p. 71. 
[18] Kalas, T.: A tanácsigazgatás gépesitésének lehetöségei és igényei, Állam és Igazgatás, 1979/1. p. 50.

[19] Kovacsics, J.: Az információs folyamatok gépesitése a tanácsi igazgatásban és a rendszerszervezés, Állam és Igazgatás, 1972/12. p. 1094.

[20] Nora, S., Minc, A.: A számitógépesitett társadalom. Statisztikai Kiadó Vállalat, Budapest, 1979. p. 107.

[21] Kalas, T.: Számitógép az államigazgatásban. Közgazdasági és Jogi Könyvkiadó, Budapest, 1979. p. 293.

[22] Kalas, T.: Számitógép az államigazgatásban. Közgazdasági és Jogi Könyvkiadó, Budapest, 1979. pp. 295-297.

[23] Kalas, T., Torma, A.: Számitástechnika a közigazgatásban, Borsodi Szemle, 1987/1. p. 25.

[24] Az alkalmazott nyilvántartásokról, programokról lásd bővebben: Zeisler, J.: Számítógépes adatkezelés fejlesztése a tanácsoknál, Állam és Igazgatás, 1984/10. pp. 921-925.

[25] Ribling, F.: Az egységes számitástechnika megteremtéséért, Állam és Igazgatás, 1988/1. p. 29.

[26] Az Elektronikus Kormányzati Gerinchálózat kialakításáról szóló 1122/2001. (XI. 22.) Korm. határozat alapján.

[27] Az egyes kormányzati célú hálózatokkal összefüggő kormányrendeletek módosításáról szóló 169/2013. (V. 29.) Korm. rendelet 32. § (22) bekezdése alapján.

[28] Budai, B. B.: E-közigazgatási alapismeretek NKE http://www.kormanyhivatal.hu/download/e/fb/c0000/szakszoveg_e_kozig_alapism(1).pdf (2018.11.10.)

[29] Kun, L.: Automatizálás a közigazgatásban? - Az informatikai alkalmazások trendjei a digitalizáció kiteljesedésének időszakában, Új Magyar Közigazgatás, 2017/2. p. 73.

[30] Az önkormányzati ASP rendszerröl szóló 257/2016. (VIII. 31.) Korm. rendelet 1. § 6. pont alapján.

[31] Csáki, Gy. B.: Kérdésfelvetések az e-közigazgatás fogalmának meghatározása körében, Infokommunikáció és jog, 2008/7. p. 278. 